\title{
Demandas judiciales contra cirujanos
}

\author{
Lawsuits against surgeons
}

\section{Arturo Prado S. ${ }^{1}$}

La mayoría de los cirujanos somos demandados al menos una vez en nuestras carreras ${ }^{1}$.

Muchos dicen "que es parte de nuestro trabajo" por lo que es una obligación decirle a los becados que la judicialización de nuestras acciones es siempre factible y cada día más frecuente.

Los errores solo se pueden minimizar y de ellos debemos aprender, pero es imposible eliminarlos por completo, porque somos seres humanos.

Cuando se materializa una demanda judicial, nos sentimos agotados, estresados, insatisfechos profesionalmente y este impacto se parece mucho a las preocupaciones que generan los temas financieros, la presión por tener éxito, los conflictos en el hogar y/o el trabajo y el sufrimiento y/o la muerte de los pacientes.

A la verguenza, ansiedad, remordimiento, frustración, duda, miedo, ira, insomnio e irritabilidad, se suma la recomendación del abogado de no hablar del caso con nadie ${ }^{2}$.

La familia nos brinda todo el apoyo del mundo, pero aun así, y a pesar de todo lo que hacen por nosotros, es casi imposible sentirse seguros.

El aislamiento aumenta nuestras dudas y erosiona nuestra confianza, llevándonos a pensar en lo que puede salir mal en vez de enfocarse en la solución de nuestro problema.

Cada una de nuestras decisiones está llena de ansiedad y nuestra eficiencia quirúrgica disminuye. Se nos produce una especie de parálisis emocional, que nos lleva a la desvinculación del cuidado de los pacientes y que, eventualmente, nos hace cometer nuevos errores.

Para muchos, la salida, está en la resiliencia, y lo que implica reestructurar nuestros recursos psicológicos en función de las nuevas circunstancias ayudándonos a recuperar el equilibrio, la elasticidad y la forma que teníamos antes de ser demandados.

Un cirujano resiliente debe permanecer completamente presente, ser capaz de superar las adversidades y utilizarlas para crecer; debe conocer sus limi- taciones, pero a la vez desarrollar todo su potencial (autoconocimiento), poner las cosas en perspectiva, seguir siendo creativo, optimista, objetivo, tenaz, flexible al cambio y controlando al máximo las emociones para lograr rodearse de colegas con actitudes positivas. Todo lo anterior ayuda a mantener una satisfacción muy alta relacionada con el trabajo y desarrollar actitudes que los mantengan atentos y esperanzados.

Los cirujanos resilientes, en vez de reducir las actividades quirúrgicas o los horarios de trabajo, deben seguir interactuando y discutiendo casos, tratamientos, resultados y que siempre incluyan una discusión franca de sus propios errores y nunca dejar de lado la docencia, asesorías, tutorías y el fortalecimiento las relaciones familiares.

En la actualidad, la resiliencia solo depende de los esfuerzos individuales; pero así como la seguridad de los pacientes es responsabilidad de las instituciones y de las comunidades quirúrgicas, también el bienestar y el apoyo que debemos sentir deben fomentarse tanto en los buenos como en los malos momentos.

No es frecuente que las corporaciones de asistencia quirúrgica (y que nada tienen que ver con los seguros y los abogados que se dedican a las prácticas de defensa médica) nos apoyen en este sentido.

Las organizaciones exitosas hablan y promueven la resiliencia individual y colectiva y debería ser un deber de la Sociedad de Cirujanos de Chile, de acoger y aconsejar a los cirujanos demandados y nunca dejarlos solos.

\section{Referencias}

1. Karl Richard C. Los orígenes de las reclamaciones por negligencia profesional. Annals of Surgery 2007;246:712-3.

2. Kelly JD. Estrés por negligencia médica. Orthopedics 2008;31:1.
'Clínica Quilín, Universidad de Chile.

Correspondencia a: prado.arturo@gmail.com 